\title{
PREFERENSI DAN VOTING BEHAVIOR DI KALANGAN MAHASISWA UNWIRA MENJELANG PEMILIHAN UMUM GUBERNUR PROVINSI NTT 2018
}

\author{
PREFERENCE AND VOTING BEHAVIOR OF THE WIDYA MANDIRA \\ CATHOLIC UNIVERSITY STUDENTS IN THE 2018 GUBERNATORIAL ELECTION \\ OF THE NTT PROVINCE
}

\author{
MARIANUS KLEDEN* \\ Fakultas Ilmu Sosial dan Ilmu Politik Universitas Katolik Widya Mandira, Kupang \\ *Email: marianus_kleden@yahoo.com
}

\begin{abstract}
Abstraksi
Pemilihan umum untuk memilih gubernur dan wakil gubernur NTT berakhir dengan dilantiknya Victor Bungtilu Laiskodat dan Yosef Nai Soi sebagai gubernur dan wakil gubernur NTT. Hasil ini nampaknya tidak sejalan dengan ekspektasi mahasiswa, khususnya mahasiswa Unika Widya Mandira. Melalui sebuah kuesioner yang disebarkan di kalangan mahasiswa, ditanyakan siapakah pasangan yang menjadi preferensi mereka. Jawabannya, 44,77 persen mahasiswa memilih pasangan Marianus Sae-Emi Nomleni sebagai gubernur-wakil gubernur, disusul Benny HarmanBenny Litelnoni pada tempat kedua dengan 25,58 persen suara dan Victor-Yosef pada posisi ketiga dengan 20,35 persen suara. Dalam pemberian suara di TPS, para pemilih rupanya terpesona dengan janji-janji bombastis selama kampanye oleh para kandidat, tetapi mahasiswa pastilah lebih tertarik dengan performans actual dari para calon, baik di bidang eksekutif maupun di bidang legislatif. Lebih dari itu, mahasiswa juga mengharapkan agar pasangan yang menang dalam pemilihan gubernur bisa memberi perhatian pada peningkatan kesejahteraan $(88,14 \%)$, kesehatan $(83,59 \%)$, pendidikan $(78,67 \%)$ dan toleransi dalam hidup beragama $(78,0 \%)$ yang mereka percaya dapat direalisasikan oleh Marianus Sae-Emi Nomleni sebagai gubernur dan wakil gubernur.
\end{abstract}

Kata Kunci: pemilihan umum, tindakan memilih, preferensi politik

\begin{abstract}
Provincial general election to elect the governor of NTT has resulted in the installment of Victor Bungtilu Lasikodat as the governor of NTT and Joseph Naisoi as the vice governor. This result does not seem to accord with the expectation of the college students, i.e., the students of Widya Mandira Catholic University to be specific. Through a questionnaire the students were asked which of the candidates become their preference. It turned out that 44,77 percent of the students preferred Marianus Sae-Emi Nomleni, followed by Benny Harman-Benny Litelnoni at the second place with 25,58 percent. Victor-Joseph came in the third place with 20,35 percent. Voters in the election were attracted by bombastic promises during the campaign but students were more attracted by the actual performance of the candidates either in the government or in the legislature. More than that the students are expecting that the future governor can take care of several urgent issues such as better prosperity $(88,14 \%)$, health (83,59\%), education $(78,67 \%)$ and religious tolerance $(78,0 \%)$ which they believed can be realized by Marianus Sae dan Emi Nomleni as their future governor and vice governor.
\end{abstract}

Key words: general election, voting behavior, political preference 


\section{Pendahuluan}

Tanggal 27 Juni 2018 diadakan pemilihan umum kepala daerah untuk memilih gubernur di beberapa provinsi di Indonesia periode 2018-2023, termasuk di NTT. Beberapa bulan menyongsong pesta demokrasi ini partai-partai politik melakukan konsolidasi dan koalisi untuk penjaringan dan penyaringan calon. Ada juga individu yang ingin maju sebagai calon independen dengan mengandalkan kekuatan dan sumber daya dalam masyarakat sipil.

Pada mulanya banyak nama yang disebut. Ada yang disebut secara eksplisit lalu menimbulkan gaung yang besar, tetapi ada yang diucapkan dengan suara kecil yang menghasilkan gaung yang kecil saja. Nama-nama yang sempat beredar antara lain Raymundus Fernandes, S.Pt (Bupati Timor Tengah Utara), Drs. Kristo Blasin (mantan anggota DPRD Provinsi NTT dari Partai PDIP), Dr. Drs. Ayub Titu Eki (Bupati Kabupaten Kupang), Dr.dr. Hyronimus Fernandez (Sekretaris BAPPEDA NTT), Drs. Marthen Dira Tome (Bupati Sabu Raijua, yang kemudian menjadi terpidana kasus korupsi dana PLS dan kini mendekam di penjara), Melki Lakalena (Ketua DPD Golkar NTT), Brigen Pol. (purn) Jacky Ully (mantan Kapolda NTT), AKBP Dr. Christofel Bagaisar, S.Pd, SS, M.Pd (Kasubditgasum Direktorat Sabhara Polda NTT), Alexander Take Ofong, S.Fil (Wakil Ketua DPRD Provinsi NTT, Sekretaris DPD Partai Nasdem), Drs. Esthon Foenay, M.Si (mantan Wakil Gubernur NTT), Drs. Chris Rotok (mantan Bupati Manggarai), Marianus Sae (Bupati Ngada), Dr. Benny K. Harman (anggota DPR RI dari Partai Demokrat, Wakil Ketua Komisi III), Benny Litelnoni (Wakil Gubernur NTT), Marsekal Muda (Purn) Robert Soter Marut dan Lusia Adinda Lebu Raya (Ketua Tim Penggerak PKK NTT).

Nama-nama ini sejak awal, ada yang maju sebagai calon gubernur tanpa menyebutkan pasangannya, ada yang maju secara berpasangan dan solid hingga penetapan oleh KPUD Provinsi NTT, tetapi ada pula pasangan yang kemudian bubar lagi untuk selanjutnya dibongkarpasangkan dengan orang lain. Nama yang maju secara perorangan tanpa pendamping sebagai pasangan misalnya Ray Fernandes, Kristo Blasin, Hyronimus Fernandez, Marthen Dira Tome, Christofel Bagaisar, Alex Ofong, Robert Soter Marut dan Lusia Adinda Lebu Raya. Mereka yang maju secara 'sorangan' ini pada tingkat tertentu, mungkin juga di belakang layar, sudah mewacanakan orang yang mendampingi mereka sebagai wakil gubernur tetapi belum dipercakapkan dan didiskusikan secara serius. Sementara yang sejak awal sudah maju sebagai pasangan adalah Esthon Foenay Chris Rotok. Esthon adalah calon gubernur dari Partai Gerindra yang memiliki 8 kursi dan Chris Rotok adalah calon dari Partai Amanat Nasional yang memiliki 5 kursi. Belakangan dimunculkan pasangan Jacky Ully-Melki Lakalena. Tidak jelas benar mengapa Golkar yang memiliki 11 kursi rela menjadi nomor 2, dipasangkan dengan Nasdem yang hanya memiliki 8 kursi. Apakah karena Jacky sebagai jenderal bintang satu purnawirawan dan mantan Kapolda ogah ditaruh sebagai orang nomor dua mendampingi seorang anak muda yang miskin pengalaman birokrasi? Ataukah ada lobi-lobi intens di tingkat DPP Nasdem dan Golkar dengan dealdeal tertentu sehingga Golkar rela menempatkan orangnya di kursi nomor 2? Belakangan pasangan ini batal diusung, lalu dimunculkan dan ditetapkan pasangan Viktor Bungtilu Laiskodat dari Partai Nasdem sebagai calon gubernur dan Yosef Nai Soi dari Partai Golkar sebagai calon wakil gubernur.

PDIP sebagai partai dengan kursi terbanyak kedua di DPRD Provinsi NTT pada awalnya memberi kesan akan mengajukan kader partainya menjadi calon gubernur NTT. Demikianlah Kristo Blasin yang adalah kader senior partai dan pernah dua kali duduk di kursi pimpinan Dewan, dan Raymundus Fernandes, Bupati TTU dan Ketua DPC PDIP TTU bergerilya memperkenalkan diri dan program-programnya dalam kunjungan dan blusukan di berbagai pelosok NTT disertai pemasangan baliho layar lebar, iklan di media arus utama dan bahkan pembuatan videotron. Dalam pembicaraan pribadi dengan beberapa pihak yang menjadi tim sukses Kristo, bahkan dengan Kristo sendiri, peneliti juga terbawa dalam arus keyakinan publik bahwa Kristo atau Raymundus akan dicalonkan oleh PDIP menjadi gubernur 
NTT periode 2018-2023. Selain kedua nama ini yang menonjol dalam diskusi publik, nama Lusia Adinda Lebu Raya sebagai Ketua Tim Penggerak PKK Provinsi NTT, sebuah nomenklatur melioratif untuk istri Gubernur petahana, Drs. Frans Lebu Raya, juga digadang-gadang oleh sekelompok orang sebagai figur yang patut diperhitungkan. Frans Lebu Raya sebagai Gubernur NTT sekaligus Ketua DPD PDIP NTT secara diplomatis selalu membantah melalui media massa bahwa dirinya menghendaki Lusia menjadi calon gubernur NTT periode 20182023.

Ketika kabar tentang Kristo Blasin, Raymundus Fernandes dan Lusia Adinda Lebu Raya belum jelas, PKB diam-diam medekati Marianus Sae, bupati Ngada petahana, agar mau dicalonkan menjadi gubernur NTT periode 2018-2023. PKB menyadari, dengan 5 kursi yang dimilikinya di DPRD Provinsi NTT, dia tidak mungkin mengajukan seorang calon gubernur yang mempersyaratkan 13 kursi atau 20 persen dari jumlah kursi yang ada di Dewan. PKB pun melirik PDIP yang memiliki 10 kursi. Berkat lobi yang intens dengan DPP PKB dan PDIP Marianus Sae lolos menjadi calon gubernur yang diusung oleh PKB dan PDIP. Marianus disandingkan dengan Emi Nomleni, kader perempuan PDIP yang adalah seorang anggota DPRD Provinsi NTT petahana. Kabar lolosnya Marianus sebagai calon gubernur yang diusung PDIP (dan PKB) terdengar seperti petir yang menyambar di siang bolong bagi para kader senior PDIP. Begitu mendengar keputusan ini Kristo dan Raymundus menyatakan keluar dari PDIP dan menjadi tim sukses pasangan Viktor Laiskokat dan Yosef Nai Soi. Eforia berhasilnya Marianus Sae-dan Emi Nomleni dicalonkan menjadi gubernur dan wakil gubernur ternyata tidak berlangsung lama. Marianus secara tak terduga sama sekali ditetapkan menjadi tersangka korupsi karena tetangkap tangan melakukan tindak pidana korupsi menerima suap dari seorang pemenang tender proyek pengerjaan jalan di Kabupaten Ngada, kabupaten yang sedang berada di bawah kepemimpinannya sebagai bupati. Tetapi tertangkapnya Marianus melalui OTT tidak menggugurkan pencalonan dirinya bersama Emi Nonleni. Statusnya sebagai tersangka tahanan
KPK, membuat Emi Nomleni bergerak sendirian mengampanyekan dirinya tanpa Marianus sebagai calon gubernur. Sejauh ini KPU Provinsi NTT belum mengklarifikasi status pasangan Marianus Sae-Emi Nomleni, jika seandainya pasangan ini menang dalam pilkada.

Dalam pada itu Benny Kabur Harman, doktor hukum yang menjadi Wakil Ketua Komisi III, Komisi yang membidangi Hukum, Hak Asasi Manusia dan Keamanan, berhasil mendekati Benny Litelnoni, wakil gubernur petahana untuk menjadi calon wakilnya di periode berikut. Benny Kabur Harman, atau yang populer dikenal dengan $\mathrm{BKH}$, yang oleh beberapa kalangan diprediksi tidak bakal lolos menjadi calon gubernur karena minimnya dukungan partai berkursi, ternyata berhasil menggaet PKS yang berkursi dua dan PKPI yang berkursi tiga di DPRD Provinsi. Dengan 8 kursi yang dimiliki Partai Demokrat ditambah 3 dari PKPI dan 2 dari PKS, jadilah pasangan BennyBenny mendaftar di KPU sebagai calon gubernur dan calon wakil gubernur dengan nama sandi Paket Harmoni.

Dengan demikian empat pasang bakal calon yang berhasil mendaftar di KPU sehingga ditetapkan sebagai calon gubernur dan calon wakil gubernur adalah pasangan-pasangan: (1) Esthon FoenayChris Rotok; (2) Viktor Bungtilu Laiskodat-Yosef Nai Soi; (3) Marianus Sae-Emi Nomleni; (4) Benny Kabur Harman-Benny Litelnoni.

Akan halnya individu-individu yang berkeinginan mencalonkan diri menjadi gubernur tetapi pada akhirnya tidak berhasil, peneliti dapat mengemukakan konstatasi sebagai berikut. Dr.dr. Hyronimus Fernandez, Sekretaris Bappeda NTT, Marsekal Muda (Purn.) Robert Soter Marut, atau AKBP Dr. Christofel Bagaisar sebagai senior di bidangnya masing-masing memperlihatkan sikap kuasi-apolitis atau sikap "malu-malu" yang sesungguhnya tidak boleh ada dalam dunia politik. Di sana sini ada satu dua spanduk atau baliho dalam ukuran sedang dan kecil terpasang di cabang pohon atau di tempat yang kurang strategis dan bukan di space iklan berbayar di Kota Kupang. Pendekatan kepada kelompok pendukung pun dilakukan dalam skala kecil, jarang ada iklan atau berita advertorial 
di media arus utama, dan hampir tidak ada lobi-lobi dengan partai-partai politik berkursi. Umumnya khalayak mafhum bahwa yang dimaksudkan dengan lobi politik dengan partai politik adalah pembicaraan mengenai "take and give", baik dalam arti finansial maupun dalam arti posisi strategis serta peluang lukratif yang bisa diberikan kepada kader partai, apabila yang bersangkutan menang dalam pilkada. Hal-hal ini praktis tidak dilakukan oleh Hyronimus, Robert Marut maupun Christofel. Posisi mereka sebagai senior yang menjadi rujukan di instansinya yang selalu "dicari”, membuat mereka sungkan atau kikuk untuk "mencari" partai dan mencari massa demi "menjual diri".

\section{Situasi Sosial Budaya Berkaitan dengan Pilkada}

NTT merupakan sebuah provinsi yang amat heterogen secara etnik. Dari barat Pulau Flores sampai ujung timur kita dapati kelompok etnikkelompok etnik sebagai berikut: Manggarai, Riung, Bajawa, Nagekeo, Ende, Lio, Sikka, Lamaholot. Bila kita melangkah ke Pantar dan Alor kita temukan sub-etnik Lamaholot karena di Pantar dan Alor ada varian bahasa Lamaholot dengan sistem kekerabatan dan sistem religi yang sama seperti yang dipraktikkan di wilayah Flores Timur dan Lembata. Menyeberangi Selat Ombai kita memasuki wilayah Kabupaten Malaka dan Belu yang penduduknya merupakan penutur bahasa Tetun dengan sedikit penutur Bunaq dan Marae - untuk mudahnya kita menyebut penduduk di kedua Kabupaten ini sebagai penghayat budaya Timor-Tetun; beranjak ke selatan kita memasuki Kabupaten TTU, TTS, Kabupaten Kupang dan Kota Kupang yang mayoritas penduduknya merupakan penghayat budaya Dawan, sehingga untuk mudahnya kita menyebut mereka sebagai berasal dari etnik Timor-Dawan. Di lepas pantai Kota Kupang dan Kabupaten Kupang kita dapati Pulau Semau yang penduduknya merupakan penghayat budaya Helong. Juga sepanjang pesisir barat Kabupaten kita kita jumpai penutur Bahasa Helong dan penghayat budaya Helong.

Di sebelah selatan kita dapati Pulau Rote yang menjadi tempat tinggal penduduk dari etnik Rote dan Pulau Sabu yang didiami penduduk beretnik
Sabu. Ke arah Barat terdapat pulau besar ketiga NTT, yaitu pulau Sumba. Walaupun terdapat banyak bahasa di pulau ini, kita dengan mudah menyebut penduduk di pulau ini sebagai penduduk beretnik Sumba karena kesamaan dalam sistem religi dengan Merapu sebagai core-belief, upacara inisiasi, sistem kekerabatan, sistem perbelisan, dan ritual kematian yang mengingatkan kita akan budaya megalitik.

Secara agama NTT yang berpenduduk 5.121.061 jiwa terdiri atas 55,19 persen penduduk beragama Katolik, 35,29 persen penganut Protestan, 9,30 persen pemeluk Islam, 0,21 berkepercayaan Hindu, dan 0,01 penghayat agama Budha (NTT dalam Angka 2016:213). Statistik resmi yang diterbitkan oleh pemerintah tidak menyebut penghayat agama asli seperti Marapu di Sumba dengan jumlah penganut sebesar 12.710 jiwa (PosKupang.com 9 Feb.2017) Jingitiu di Sabu dengan pengikut sebesar 8.000 jiwa atau 10 persen penduduk Sabu (sergapntt.com 24/4/2012) dan Halaika di Boti, TTS, yang ajarannya dipraktikkan oleh $77 \mathrm{KK}$ atau 316 jiwa (nomor1.com). Jumlah penghayat agama asli sebesar kurang lebih 30.000 jiwa atau hampir 6 kali lebih banyak dari penganut Budha atau 3 kali lebih banyak dari penganut Hindu yang ada di NTT membuat mereka pun patut diperhitungkan dalam dinamina perpolitikan di NTT.

Dari data yang ditampilkan kelihatan bahwa NTT adalah provinsi yang amat heterogen secara etnik dan agama. Dengan demikian dalam proses rekrutmen calon gubernur dan wakil gubernur maka selalu ada pertimbangan geopolitik berbasis agama dan etnik. Dua agama dengan penganut terbesar, Katolik dan Protestan, selalu menjadi dasar pertimbangan. Apabila calon gubernurnya berasal dari Flores yang Katolik maka wakil gubernurnya berasal dari Timor-Sumba-Rote-Sabu yang Protestan. Sebaliknya kalau calon gubernurnya berasal dari selatan yang Protestan maka calon wakil gubernurnya berasal dari utara yang Katolik.

Kondisi sosial lainnya yang menjadi bahan pertimbangan dalam rekrutmen calon gubernur dan wakil gubernur adalah kenyataan bahwa 22,65 persen penduduk terkategori miskin (NTT dalam Angka, 2017:226). Pertanyaan yang diajukan 
berkaitan dengan kondisi miskin ini adalah, apakah si calon mampu membiayai semua ongkos politik termasuk membayar mahar yang jumlahnya sangat besar ke partai politik pengusung dan pendukung. Apakah yang bersangkutan punya cukup dana untuk mengiklankan dirinya di media sosial dan media main-stream, mencetak baliho dan memasangnya di space iklan berbayar, serta menyelenggarakan kampanye panggung yang dihadiri ribuan massa? Mampukah ia memobilisasi puluhan pengendara kendaraan roda dua yang meramaikan konvoi penyambutan dan mendatangkan artis-artis ibukota guna menarik khalayak? Kemiskinan ini berakibat pada kenyataan bahwa banyak tokoh potensial dengan pengalaman yang kaya dalam politik dan birokrasi, dengan integritas yang teruji, dengan kematangan kepemimpinan dalam menghadapi banyak masalah, tidak mampu tampil sebagai calon. Demikian pula para bupati atau ketua DPRD atau jabatan-jabatan selevel yang ingin naik ke jenjang yang lebih tinggi seperti gubernur, selalu tergoda untuk mengakumulasi modal atas cara-cara yang koruptif, sehingga ketika mereka maju, mereka terganjal kasus hukum. Kemiskinan juga berakibat pada kenyataan bahwa banyak pemilih rentan terhadap politik uang, sehingga keputusannya untuk memilih si A atau si B, tidak pertama-tama didasarkan pada pencermatan terhadap kapasitas calon, melainkan pada seberapa besar uang dan hadiah yang telah diterimanya, atau janji-janji manis yang sulit direalisasikan tetapi mudah dipercaya karena demonstrasi kekayaan dalam kampanye yang membius kesadaran. Selanjutnya keputusan partai untuk mengusung si A atau si B kelihatannya lebih banyak ditentukan oleh pertimbangan seberapa besar mahar yang sanggup dibayarnya, dan bukan pada kapasitas dan elektabilitas bersangkutan.

Dalam kaitan dengan ciri-ciri sosial, provinsi NTT terbentuk dari kelompok-kelompok etnik yang mempraktikkan pola hidup keluarga luas dengan seorang patriark sebagai pengampu bagi seluruh anggota marga, klan atau sukunya. Antara dirinya dengan semua orang yang diampuinya terbentuk sistem ekspektasi yang mengondisikan si pengampu untuk mendayagunakan seluruh sumber daya bagi kesejahteraan seluruh anggota suku, klan, atau marga. Sebagai ilustrasi, para kakek kita tiga atau empat generasi lalu yang lahir di penghujung abad 19 atau awal abad 20, bila dia seorang anak sulung, maka dia bukan hanya memelihara, mendidik, menyekolahkan dan menikahkan anakanak kandungnya saja, tetapi juga memelihara, mendidik, menyekolahkan dan menikahkan anakanak dari adik-adiknya. Sang kakek memiliki mindset bahwa dia mempunyai kewajiban moral untuk memperhatikan keponakan-keponakannya, sementara para keponakan juga mengharapkan agar bapa besar mereka bisa memperhatikan kehidupannya. Pola hidup keluarga luas dalam arti ini sudah hilang, tetapi cara pikir dan pola sikap keluarga luas tetap dipraktikkan antara seorang pejabat publik dengan para kawula yang mengitari dirinya. Untuk mengokohkan dirinya sebagai seorang "patriark" masa kini, maka rumah jabatan sebagai area publik yang harus direstriksi bagi pelayanan publik mulai disalahgunakan untuk kepentingan komunal sempit: para keponakan datang dan pergi, makan dan minum di dapur rumah jabatan, tidur di banyak ranjang yang direservasi untuk tamu, dan mungkin secara tidak langsung minta diongkosi sekolahnya. Inilah cikal bakal korupsi berbasis sistem ekspektasi sosial. Sistem ekspektasi inilah yang menjadi salah satu motif utama ketika para pemilih menjatuhkan pilihannya atas calon-calon yang disodorkan partai pengusung.

Pada level lain, mungkin tidak terjadi korupsi tetapi sistem ekspektasi yang berimpitan dengan sukuisme membuat seseorang dengan hak suara tidak memilih berdasarkan kapabilitas calon melainkan berdasarkan kebanggaan sukuistik bahwa salah seorang putra atau putri mereka boleh mengemban sebuah tugas publik yang menginsinuasikan peran seorang patriark yang memberikan perlindungan dan kesejahteraan patrimonial bagi rakyat yang dipimpinnya.

Pola hidup keluarga luas yang patriarkis dan patrimonial berakibat pada kenyataan bahwa dalam mengampanyekan diri, seorang calon merekrut tim sukses berbasis keluarga dan pertemanan. Watak patriarkis juga menciptakan kondisi di mana tokoh perempuan potensial kurang dilirik. Selanjutnya 
bila sang calon terpilih menjadi gubernur, maka pembentukan "kabinet" merujuk kepada prinsip balas jasa dan balas dendam. Demikianlah mereka yang membantu seorang calon sebagai tim sukses - yang nota bene merupakan tim dengan ikatan keluarga dan pertemanan - akan diberi posisi strategis, dan mereka yang menjadi tim sukses rival akan terdepak dan tidak diperhatikan dalam rekrutmen pembentukan OPD.

\section{Situasi Seputar Mahasiswa Menjelang Pilkada}

Setelah mencermati situasi seputar rekrutmen calon menjelang pemilukada maupun situasi sosial budaya yang mengitarinya, pertanyaan berikut berkaitan dengan penelitian ini adalah, apakah mahasiswa pada umumnya ikut memberikan suaranya dalam pemilu? Ataukah mahasiswa cenderung tidak memberikan suaranya? Kalau memberikan suaranya dalam pemilu, apakah ada polanya? Kalau tidak memberikan suaranya apakah dia mempunyai alasan mendasar?

Dari 66 perguruan tinggi yang ada di NTT, provinsi ini memiliki 56.714 mahasiswa atau kurang lebih 1 persen dari jumlah penduduk (NTT dalam Angka, 2016:192). Walaupun jumlahnya kecil secara demografis, mahasiswa merupakan kelompok yang rasional dan kritis terhadap penyelenggaran pemerintahan, termasuk penyelenggaraan pemilukada. Kelemahan-kelemahan yang sempat dipantau oleh mahasiswa dalam kaitan dengan pemilukada misalnya ditemukannya "pemilih ganda, NIK ganda, alamat ganda, pemilih nyasar, pemilih di bawah umur/balita, pemilih yang berstatus TNI/ POLRI, pemilih yang terselip, pemilih yang sudah meninggal dunia, pemilih yang masuk dalam DPS tetapi tidak masuk dalam DPT" (Pradhanawati, 2010: 181).

Kelemahan KPU sebagai penyelenggara pemilu bukan hanya sesuatu yang tipikal Indonesia tetapi dilakukan juga oleh negara lain, seperti Malaysia, yang menyelenggarakan 'pemilihan raya' di Indonesia untuk warga negara Malaysia yang ada di Indonesia. . Sebuah studi yang dilakukan Budiarjo dan Setiawan (2015:31) tentang perilaku memilih di kalangan mahasiswa Malaysia yang ada di Indonesia menemukan bahwa mahasiswa Malaysia yang ada di Indonesia umumnya tidak ikut memberikan suaranya dalam pemilihan raya (istilah Malaysia untuk pemilihan umum) yang diselenggarakan KPU Malaysia karena mahasiswa tidak percaya kepada keputusan negara yang dikuasai Barisan Nasional yang merupakan koalisi partai terbesar di Malaysia, dan ketidakpercayaan kepada KPU sebagai lembaga yang bisa menyelenggarakan pemilu yang adil dan jujur. Singkat kata, sebagaimana hasil penelitian Suryanef (2011: 175) mahasiswa merupakan kelompok pembaru yang serba skeptis dan mendorong dipercepatnya realisasi agenda-agenda reformasi. Mereka merupakan kelompok manusia usia muda yang karena bertambahnya pengetahuan dan wawasan, menjadi kritis dan idealis serta skeptis terhadap program-program pembangunan dan penyelenggaraan negara pada umumnya.

Secara hipotetis tetapi juga empiris, perilaku dan cara pandang mahasiswa ini juga berlaku untuk mahasiswa NTT, secara spesifik mahasiswa Unwira yang menjadi objek dan subjek kajian ini.

\section{Realitas Pemilu dan Kiprah Mahasiswa}

Dari deskripsi empirik di atas terlihat bahwa (1) Pemilukada adalah sarana demokrasi atau sarana mewujudkan kedaulatan rakyat tetapi dalam kenyataan pemilukada menjadi sarana pelanggengan kekuasaan; (2) Pemilukada menjadi sarana pelanggengan kekuasaan karena tekanan sosial budaya dan tekanan sosial ekonomi; (3) Mahasiswa adalah kelompok idealis yang memperjuangkan good governance dan clean government termasuk penyelenggaraan pemilukada sesuai aturan, tetapi karena dalam kenyataan pemilu dan pemilukada berlangsung secara curang, maka mahasiswa menjadi skeptis dan apatis untuk memberikan suara dalam pemilu/pemilukada.

Dalam kaitan ini dapat diajukan pertanyaan lebih lanjut untuk didalami yaitu, apakah mahasiswa masih percaya kepada pemilu sebagai sarana perwujudkan demokrasi dan karena itu masih mau mencoblos atau menjadi apatis dan tidak ingin memberikan suaranya. Jawaban atas pertanyaan ini dilakukan melalui pemberian kuesioner kepada 250 mahasiswa Fakultas Ilmu Sosial dan Ilmu Politik, Fakultas Keguruan dan Ilmu Pendidikan, Fakultas 
Teknik dan Fakultas Filsafat.

\section{Kerangka Teoretik dan Praktik Memilih di Kalangan Mahasiswa}

Dalam studi yang dilakukan oleh Lipset (1981: 190), yang boleh dipandang sebagai salah satu klasik dalam teori politik, dikatakan bahwa orang memberikan suaranya dalm pemilu karena (1) Relevansi kebijakan pemerintah terhadap individu. Dengan kata lain, program-program pembangunan pemerintah dirasa menguntungkan diri dan kelompok; (2) Akses kepada informasi, yaitu bahwa seluruh informasi menyangkut kandikat diketahui oleh calon pemilih; (3) Tekanan kelompok, baik kelompok pendukung maupun kelompok penentang.

Bila teori Lipset disandingkan dengan penelitian lain dalam konteks kekinian maka terlihat bahwa ketika hendak memilih, mahasiwa itu seperti berbelanja ke supermarket dan melihat etalase. Kalau pajangannya menarik dia akan membeli (Esita 2014: 149). Ini bolehlah disejajarkan dengan alasan akses kepada informasi sekaligus alasan pengalaman akan program pemerintah yang menguntungkan pemilih dan kelompoknya. Sejalan dengan ini calon pemilih pemula tidak akan memilih bila kandidat tidak menyosialisasikan dirinya dan program kerjanya (Muslim, 2013). Sebaliknya juga benar, mahasiswa justru tidak memilih karena sudah mengetahui sepak terjang seorang kandidat dalam petualangannya di dunia politik dan birokrasi seperti mahasiswa asal Malaysia di Indonesia yang tidak mau berpartisipasi dalam pemilihan raya, karena tahu kecurangan KPU dalam memenangkan calon dari Barnas, partai yang justru tidak peka terhadap aspirasi rakyat (Budiarjo dan Setyawan, 2015).

Alasan tekanan kelompok hanya relevan ketika kita berbicara tentang Orde Baru. Orde Baru di bawah rezim Suharto menciptakan sebuah sistem yang membuat sebagian besar warga negara terkondisikan untuk memilih Golkar. PNS "dicuci otaknya" untuk meyakini bahwa setiap bulan dia menerima gaji dan beras dari Golkar. Dengan demikian apabila ada anak dari PNS yang bersikap kritis dan memilih partai lain, maka anak tersebut akan dianggap sebagai anak durhaka yang tidak tahu berterima kasih. Demikian pula halnya dengan pengusaha swasta. Seluruh mekanisme perizinan akan dipersulit bila dia bukan anggota Golkar dan dipermudah bila dia menjadi pengurus Golkar. Suasana represif seperti ini tidak dialami mahasiswa di era Orde Reformasi. Namun demikian "tekanan kelompok" bisa dimengerti secara negatif: mahasiswa beramai-ramai memilih golput karena berada di bawah tekanan pencitraan kolektif tentang sebuah pemerintahan yang korup.

Di Indonesia kampanye untuk menjadi golput (golongan putih) alias tidak memilih dilatarbelakangi ketidakpercayaan terhadap elite politik. Anggota Dewan dan pemerintah tidak lagi dipercaya memperjuangkan nasib rakyat. Itulah sebabnya angka golput terus naik dari masa ke masa. Angka golput di Indonesia bertambah dua kali lipat dalam pemilu legislatif dan pemilu presiden pada tahun 2004, yaitu 23\% dan 21\%. Angka ini terus naik di dalam pemilu legislatif dan pemilu presiden pada 2009, yaitu 29\% dan 29,1\%. Bahkan hal ini terjadi juga dalam tiga tahun terakhir. Banyak pihak yang menyatakan peningkatan angka golput dari tahun ke tahun disebabkan kualitas partai dan calon legislator atau calon presiden yang tidak baik (Utami, 2016).

\section{Bagaimana dengan Mahasiswa Unwira?}

Dari 250 kuesioner yang disebarkan di 4 fakultas, hanya 172 lembar dikembalikan atau 68,8 persen. Jadi perhitungan hanya didasarkan atas data yang ada. Jawaban atas pertanyaan mahasiswa dibuat dalam 6 tingkatan skala Likert. Siapakah calon yang menjadi preferensi mahasiswa dapat dilihat dalam tabel di bawah ini.

Tabel 1. Paslon Gubernur yang akan dilipih

\begin{tabular}{|l|l|c|c|}
\hline No & Paslon gubernur-wakil gubernur & N & $\begin{array}{c}\% \\
\text { elektabilitas }\end{array}$ \\
\hline 1 & Marianus Sae-Emi Nomleni & 77 & 44,77 \\
\hline 2 & BKH-Benny Litelnoni & 44 & 25,58 \\
\hline 3 & Victor Laiskodat-Josef Nai Soi & 35 & 20,35 \\
\hline 4 & Esthon Foenay-Christian Rotok & 9 & 5,23 \\
\hline 5 & Tidak memilih & 7 & 4,07 \\
\hline & Jumlah & 172 & 100 \\
\hline
\end{tabular}


Mengapa mahasiswa cenderung memilih MSEmi di atas paslon lainnya? Jawaban atas pertanyaan ini dapat dibagi dalam dua kategori alasan, yaitu alasan rasional dan alasan primordial-emosional. Yang termasuk dalam alasan rasional adalah kejelasan visi-misi paslon, kemampuannya meningkatkan kesejahteraan rakyat, kemampuannya mencegah korupsi dan nepotisme, kekayaan calon, pendidikan calon, kecerdasan paslon berargumentasi, pengalaman paslon di bidang eksekutif dan legislatif serta kemampuan paslon berkomunikasi dengan Jakarta - semuanya sejauh dipersepsi oleh mahasiswa. Sedangkan yang termasuk dalam alasan primordial-emosional adalah sifat kemerakyatan paslon, asal partai yang sama, asal daerah yang sama, dan asal agama yang sama.

\section{Alasan Rasional Mahasiswa Memilih Paslon}

Tabel 2. Pandangan mahasiswa terhadap kejelasan visi-misi paslon

\begin{tabular}{|l|l|l|l|l|}
\hline No & Paslon gubernur-wakil gubernur & N & $\begin{array}{l}\text { T o t a 1 } \\
\text { penilaian }\end{array}$ & $\begin{array}{l}\text { Rata-rata } \\
\text { pd skala L }\end{array}$ \\
\hline 1 & Marianus Sae-Emi Nomleni & 77 & 328 & 4,26 \\
\hline 2 & BKH-Benny Litelnoni & 44 & 165 & 3,75 \\
\hline 3 & Victor Laiskodat-Josef Nai Soi & 35 & 131 & 3,74 \\
\hline 4 & Esthon Foenay-Christian Rotok & 9 & 43 & 4,78 \\
\hline
\end{tabular}

Dari Tabel di atas terlihat bahwa paslon Esthon-Chris mempunyai visi misi yang paling jelas, atau berada pada skor 4,78 skala Likert namun penilaian ini tidak begitu signifikan karena diberikan oleh hanya 5,23 persen responden, sedangkan penilaian terhadap visi-misi MS-Emi berada pada skor 4,26 atau sedikit di bawah EsthonChris tetapi diberikan oleh 44,77 persen responden. Kalau dikonversikan ke dalam angka 0-100 maka nilai Esthon-Chris adalah 95,60 dan nilai MSEmi 85,20. Sementara tingkat kejelasan visi-misi BKH-BL dan Victor-Josef berada pada angka yang hampir sama yaitu 3,75 untuk BKH-BL dan 3,74 untuk Victor-Josef. Bila dikonversikan ke dalam angka 0-100 maka nilai visi BKH-BL adalah 75 sedangkan untuk Victor-Josef 74,80.

Berikut akan diperiksa apakah kepercayaan terhadap visi-misi paslon berbanding lurus dengan keyakinan bahwa pasangan dengan skor tertinggi merupakan pasangan yang paling mampu meningkatkan kesejahteraan rakyat NTT.

Tabel 3. Pandangan mahasiswa terhadap kemampuan paslon meningkatkan kesejahteraan rakyat

\begin{tabular}{|l|l|l|l|l|}
\hline No & Paslon gubernur-wakil gubernur & N & $\begin{array}{c}\text { Total } \\
\text { penilaian }\end{array}$ & $\begin{array}{c}\text { Rata-rata } \\
\text { pd skala L }\end{array}$ \\
\hline 1 & Marianus Sae-Emi Nomleni & 77 & 303 & 3,93 \\
\hline 2 & BKH-Benny Litelnoni & 44 & 167 & 3,79 \\
\hline 3 & Victor Laiskodat-Josef Nai Soi & 35 & 122 & 3,48 \\
\hline 4 & Esthon Foenay-Christian Rotok & 9 & 41 & 4,55 \\
\hline
\end{tabular}

Dari Tabel 3 terlihat bahwa skor untuk kemampuan paslon meningkatkan kesejahteraan rakyat NTT umumnya lebih rendah dibadingkan dengan skor untuk kejelasan visi-misi, dengan kecualian pada BKH-BL. Dengan kata lain, dalam pandangan mahasiswa, visi misi yang bagus belum tentu direalisasikan dalam kadar yang sama ketika berlangsung penyelenggaraan pemerintahan. Dari aspek ini terlihat penurunan yang signifikan pada pasangan Victor-Josef. Bila dikonversikan ke angka 0-100 maka skor kepercayaan mahasiswa terhadap kemampuan paslon Victor-Josef dalam meningkatkan kesejahteraan rakyat NTT berada pada angka 69,6 atau turun 5,20 dari 74.80 untuk kejelasan visi.

Skor kemampuan MS-Emi dalam meningkatkan kesejahteraan juga berada di bawah skor kejelasan visi misi. Bila kejelasan visi misi mendapat skor 4,26 atau 85,20 maka skor untuk kemampuan meningkatkan kesejahteraan rakyat NTT turun menjadi 3,93 atau 78,60 sementara skor untuk Esthon-Chris masih bertengger di angka tinggi yaitu 4,55 atau 91. Dalam pada itu skor untuk BKH-BL naik sedikit dari 3,75 atau 75 menjadi 3,79 atau 75,80. Walaupun angkaangka ini kecil, implikasi yang bisa disimak ialah, kemampuan panggung dan kemampuan berkatakata dalam komunikasi yang simpatik tidak begitu mudah menggugah kepercayaan publik, secara khusus publik terpelajar, terhadap kemampuan maupun kejujuran paslon untuk merealisasikan apa yang dikatakannya. Menarik, bahwa BKH merupakan calon gubernur yang paling "tidak komunikatif" dalam mempromosikan diri. Dan watak "tidak komunikatif" bisa dilihat akibatnya dalam perolehan suara dalam pemilukada yang 
dilaksanakan pada tanggal 27 Juni 2018. Namun watak kurang komunikatif ini tidak menurunkan kepercayaan mahasiswa terhadap kemampuannya meningkatkan kesejahteraan rakyat NTT. Dengan lain perkataan, kepercayaan terhadap kemampuan seorang calon pejabat publik untuk meningkatkan kesejahteraan rakyat tidak pertama-tama didasarkan atas apa yang dikatakan, melainkan atas apa yang telah dilakukan atau atas penelurusan terhadap rekam jejak.

Pertanyaan berikut adalah, apakah paslon sanggup mencegah korupsi dan nepotisme. Terhadap pertanyaan ini, kita dapat melihat jawabannya yang merupakan sikap mahasiswa dalam Tabel 4 di bawah ini.

Tabel 4. Pandangan mahasiswa terhadap kemampuan paslon mencegah korupsi dan nepotisme
Dalam kampanye, para paslon sering mendeskripsikan dirinya sebagai "kami sudah selesai dengan diri kami sendiri”. Dengan kata lain, diasumsikan bahwa kalau pasangan calon gubernur kaya dan berduit, mereka tidak perlu melakukan korupsi lagi. Itulah sebabnya peneliti mengajukan pertanyaan, apakah kekayaan bisa menjadi salah satu faktor yang memotivasi mahasiswa untuk memilih pasangan tertentu?

Tabel 5. Pandangan mahasiswa tentang kekayaan sebagai alasan memilih

\begin{tabular}{|l|l|l|l|l|}
\hline No & Paslon gubernur-wakil gubernur & N & $\begin{array}{c}\text { Total } \\
\text { penilaian }\end{array}$ & $\begin{array}{c}\text { Rata-rata } \\
\text { pd skala L }\end{array}$ \\
\hline 1 & Marianus Sae-Emi Nomleni & 77 & 138 & 1,79 \\
\hline 2 & BKH-Benny Litelnoni & 44 & 114 & 2,59 \\
\hline 3 & Victor Laiskodat-Josef Nai Soi & 35 & 118 & 3,37 \\
\hline 4 & Esthon Foenay-Christian Rotok & 9 & 20 & 2,22 \\
\hline
\end{tabular}

\begin{tabular}{|l|l|l|l|l|}
\hline No & \multicolumn{1}{|c|}{$\begin{array}{c}\text { Paslon gubernur-wakil } \\
\text { gubernur }\end{array}$} & N & $\begin{array}{c}\text { Total } \\
\text { penilaian }\end{array}$ & $\begin{array}{c}\text { Rata-rata } \\
\text { pd skala L }\end{array}$ \\
\hline 1 & Marianus Sae-Emi Nomleni & 77 & 194 & 2,52 \\
\hline 2 & BKH-Benny Litelnoni & 44 & 144 & 3,27 \\
\hline 3 & Victor Laiskodat-Josef Nai Soi & 35 & 115 & 3,28 \\
\hline 4 & Esthon Foenay-Christian Rotok & 9 & 35 & 3,89 \\
\hline
\end{tabular}

Dengan mencermati Tabel 5, terlihat bahwa pasangan MS-Emi, BKH-BL dan Esthon-Chris mempunyai skor yang rendah dalam kepemilikan kekayaan sebagai alasan keterpilihannya, sementara Victor-Josef sebagai pasangan yang lebih berduit memiliki skor

Dari Tabel 4 di atas terlihat bahwa walaupun mahasiswa cenderung memilih MS-Emi sebagai gubernur dan wakil gubernur, mereka tidak yakin pasangan ini sanggup memberantas korupsi dan mepotisme. Sebabnya jelas, yaitu bahwa MS terkena operasi tangkap tangan menerima uang (gratifikasi) dari salah satu pihak yang menang tender dalam pengerjaan proyek di Kabupaten Ngada. Dalam kenyataan di lapangan, MS berada dalam posisi kedua setelah Victor-Josef yang keluar sebagai pemenang. Ini berarti ada sentimen laten yang mempercayai bahwa MS sengaja dibidik untuk dijatuhkan dan sikap seperti ini juga diperlihatkan mahasiswa secara sporadik dan implisit dalam sikap dan tutur katanya.

BKH-BL dan Victor Josef mendapat skor yang hampir sama dalam kemampuan memberantas korupsi dan nepotisme, yaitu 3,27 untuk BKH-BL dan 3,28 untuk Victor-Josef sementara EsthonChris berada pada skor sedikit lebih tinggi yaitu 3,89. Secara keseluruhan, keempat pasangan ini mendapat skor relatif lebih rendah dalam kemampuan memberantas korupsi dan nepotisme. 
Tabel 6. Pandangan mahasiswa tentang pendidikan sebagai alasan memilih
Esthon-Chris (karena hanya dipilih oleh 5,23 persen reponden), Emi Nomleni sebagai calon

\begin{tabular}{|l|l|l|l|l|}
\hline No & Paslon gubernur-wakil gubernur & N & $\begin{array}{c}\text { Total } \\
\text { penilaian }\end{array}$ & $\begin{array}{c}\text { Rata-rata } \\
\text { pd skala L }\end{array}$ \\
\hline 1 & Marianus Sae-Emi Nomleni & 77 & 239 & 3,10 \\
\hline 2 & Benny K.Harman-Benny Litelnoni & 44 & 165 & 3,75 \\
\hline 3 & Victor Laiskodat-Josef Nai Soi & 35 & 107 & 3,06 \\
\hline 4 & Esthon Foenay-Christian Rotok & 9 & 36 & 4,00 \\
\hline
\end{tabular}

wakil gubernur meraih skor tertinggi karena penampilannya dalam debat publik boleh dibilang unggul baik dari segi substansi maupun dari dari segi diksi, gaya, dan retorika, yang membuat mahasiswa menjatuhkan pilihan pada MS-Emi.

Dari segi pendidikan, BKH mempunyai jenjang pendidikan paling tinggi dan MS-Emi adalah pasangan dengan jenjang pendidikan yang paling rendah. Tetapi dari Tabel 6 terlihat bahwa tingginya jenjang pendidikan tidak terlalu berpengaruh terhadap elektabilitas paslon. Esthon yang berpendidikan magister mempunyai skor yang lebih tinggi dari BKH yang bergelar doktor. Sementara MS yang tidak menyelesaikan pendidikan S1 di perguruan tinggi mempunyai skor sedikit lebih tinggi dari Victor yang meraih gelar magister setelah menjadi anggota DPR. Dengan kata lain pendidikan tinggi penting bagi seorang pejabat publik, tetapi pendidikan yang rendah tidak menjadi halangan bagi seorang figur untuk meraih posisi sebagai pejabat publik.

Umumnya pendidikan berkorelasi dengan ketrampilan berargumentasi. Karena itu peneliti juga mengajukan pertanyaan, apakah paslon ini juga dipilih karena kecerdasannya dalam beragumentasi.

Tabel 7. Pandangan mahasiswa tentang kecerdasan berargumentasi sbg alasan memilih

Sejauh ini peneliti sudah berbicara tentang kapasitas pribadi para paslon dari beberapa aspek, mulai dari kemampuan menjual visi misi, tingkat pendidikan, kemampuan meningkatkan kesejahteraan warga, kemampuan memberantas korupsi dan nepotisme hingga kemampuan berargumentasi dalam mempertahankan sebuah gagasan.

Berikut akan diperiksa apakah pengalaman (rekam jejak) paslon di birokrasi dan bidang legislatif telah menjadi alasan bagi mahasiswa untuk menjatuhkan pilihannya.

Tabel 8. Pandangan mahasiswa tentang pengalaman di bidang legislatif sebagai alasan memilih paslon

\begin{tabular}{|l|l|c|c|c|}
\hline No & \multicolumn{1}{|c|}{$\begin{array}{c}\text { Paslon gubernur-wakil } \\
\text { gubernur }\end{array}$} & N & $\begin{array}{c}\text { Total } \\
\text { penilaian }\end{array}$ & $\begin{array}{c}\text { Rata-rata } \\
\text { pd skala L }\end{array}$ \\
\hline 1 & Marianus Sae-Emi Nomleni & 77 & 241 & 3,13 \\
\hline 2 & BKH-Benny Litelnoni & 44 & 159 & 3,61 \\
\hline 3 & Victor Laiskodat-Josef Nai Soi & 35 & 124 & 3,54 \\
\hline 4 & Esthon Foenay-Christian Rotok & 9 & 30 & 3,33 \\
\hline
\end{tabular}

Dari Tabel 8 kelihatan bahwa mahasiswa mengapresiasi pengalaman paslon di bidang legislatif. BKH yang bergelar doktor di bidang hukum dan menjadi wakil ketua Komisi III DPR RI yang membidangi hukum dan HAM dan cukup instrumental dalam pembuatan undang-undang nampaknya mendapat apresiasi cukup tinggi (3,61 atau

Dari Tabel 7 di atas terlihat bahwa kecerdasaran berargumentasi sebagai dasar keterpilihan tidak terlalu kuat berkorelasi dengan tingginya jenjang pendidikan. $\mathrm{BKH}$ dengan jenjang pendidikan tertinggi mempunyai skor terendah dalam kecerdasan berargumentasi. Kecerdasan ini tidak semata-mata berhubungan dengan substansi materi yang disampaikan tetapi juga dengan cara dan gaya menyampaikan informasi. Dengan mengabaikan
72,20) dari mahasiswa. Apresiasi juga diberikan kepada Victor Laiskodat dan Josef Nai Soi yang keduanya merupakan anggota DPR RI juga. Pasangan nomor 4, Esthon-Chris, walaupun hanya mempunyai pengalaman di bidang eksekutif dan tidak pernah menjadi anggota $\operatorname{DPR}(\mathrm{D})$ juga mendapat skor relatif tinggi dari mahasiswa karena "pentingnya pengalaman di bidang legislatif" itu berlaku bagi siapa saja. Esthon-Chris tidak 
mempunyai pengalaman langsung di bidang legislatif tetapi pengalaman tidak langsung terjadi dalam komunikasi antara pemerintah dan Dewan ketika membahas program dan ranperda. Hal yang sama juga dialami pasangan nomor 1 MS-Emi yang merupakan gabungan dari orang-orang yang berpengalaman di bidang eksekutif dan legislatif.

Selanjutnya kita akan melihat bagaimana mahasiswa memandang pentingnya pengalaman bidang eksekutif atau birokrasi. Pandangan mahasiwa ini akan dilihat dalam Tabel 9 di bawah ini.

Tabel 9. Pandangan mahasiswa tentang pengalaman di bidang eksekutif sebagai alasan memilih paslon

\begin{tabular}{|l|l|c|c|c|}
\hline No & Paslon gubernur-wakil gubernur & N & $\begin{array}{c}\text { Total } \\
\text { penilaian }\end{array}$ & $\begin{array}{c}\text { Rata-rata } \\
\text { pd skala L }\end{array}$ \\
\hline 1 & Marianus Sae-Emi Nomleni & 77 & 298 & 3,87 \\
\hline 2 & BKH-Benny Litelnoni & 44 & 174 & 3,95 \\
\hline 3 & Victor Laiskodat-Josef Nai Soi & 35 & 114 & 3,54 \\
\hline 4 & Esthon Foenay-Christian Rotok & 9 & 39 & 4,33 \\
\hline
\end{tabular}

Penilaian atau pandangan mahasiswa terhadap pengalaman paslon di bidang eksekutif, kelihatan proporsional dengan pengalaman riil para paslon di bidang pemerintahan. Esthon-Chris yang malang melintang di birokrasi, kemudian menjadi bupati dan wakil gubernur mendapat skor paling tinggi (4,33). Tetapi dukungan dari hanya 5,23 persen responden menunjukkan bahwa pengalaman di bidang birokrasi bukanlah segala-galanya, dalam arti, secara teoretis keberadaan yang terlalu lama di birokrasi bisa menjadi penghambat inovasi, karena seorang eksekutif dapat saja terkungkung regulasi dan tidak ada keberanian untuk membuat gebrakan inovatif. Posisi kedua diraih oleh pasangan BKH-BL dengan skor 3,95. BKH mengambil Benny Litelnoni sebagai calon wakil gubernur yang memang seorang wakil gubernur petahana. Posisi ketiga diraih oleh pasangan MS-Emi. MS sendiri adalah Bupati Ngada petahana yang harus berhenti dari jabatan bupati karena maju sebagai calon gubernur NTT periode 2018-2023. Pengalaman dan prestasinya sebagai bupati bukan saja diapresiasi oleh mahasiswa tetapi juga oleh masya-rakat NTT umumnya yang menempatkan dirinya sebagai pemeroleh suara terbanyak kedua sesudah pasangan Victor-Josef dalam pilgub yang baru lewat. Dalam kaitan dengan pengalaman di bidang pemerintahan ini, pasangan Victor-Josef memang tidak pernah berkecimpung secara aktif di pemerintahan sebagai pelaku, tetapi perjumpaan dan komunikasi mereka dengan pihak eksekutif tentu sudah sering dilakukan. Karena itu walaupun meraih skor terkecil di antara keempat paslon, angka 3.54 (atau 70,8 dalam rentang 0-100) secara substantif menunjukkan apresiasi mahasiswa terhadap pengalaman tidak langsung mereka di bidang eksekutif.

Tabel 10. Pandangan mahasiswa tentang kemampuan paslon berkomunikasi dengan Jakarta

\begin{tabular}{|l|l|c|c|c|}
\hline No & $\begin{array}{l}\text { Paslon gubernur-wakil } \\
\text { gubernur }\end{array}$ & N & $\begin{array}{c}\text { Total } \\
\text { penilaian }\end{array}$ & $\begin{array}{c}\text { Rata-rata } \\
\text { pd skala L }\end{array}$ \\
\hline 1 & $\begin{array}{l}\text { Marianus Sae-Emi } \\
\text { Nomleni }\end{array}$ & 77 & 229 & 2,97 \\
\hline 2 & BKH-Benny Litelnoni & 44 & 152 & 3,45 \\
\hline 3 & $\begin{array}{l}\text { Victor Laiskodat-Josef } \\
\text { Nai Soi }\end{array}$ & 35 & 128 & 3,67 \\
\hline 4 & $\begin{array}{l}\text { Esthon Foenay-Christian } \\
\text { Rotok }\end{array}$ & 9 & 22 & 2,44 \\
\hline
\end{tabular}

Seorang gubernur adalah wakil pemerintah pusat di daerah. Ini berarti dia harus sanggup menerjemakan kebijakan pemerintah pusat di daerah dan mampu melakukan komunikasi yang produktif antara provinsi dan Jakarta. Oleh karena itu peneliti ingin mencari tahu bagaimana apresiasi mahasiwa terhadap kemampuan para paslon melakukan komunikasi dengan Jakarta.

Dari Tabel 10 di atas terlihat bahwa pandangan mahasiswa tentang kemampuan melakukan komunikasi dengan Jakarta cukup objektif. Victor-Josef yang keduanya merupakan orang Jakarta yang mempunyai jejaring luas baik dengan pemerintah maupun dengan pengusaha mendapat skor tertinggi yaitu 3,67. Posisi kedua yang juga relatif tinggi diraih oleh pasangan $\mathrm{BKH}$ BL. Posisinya yang lebih rendah dari pasangan Victor-Josef masuk akal karena Benny Litelnoni yang merupakan calon wakil gubernur bukan orang Jakarta. Pasangan MS-Emi dan EsthonChris sama-sama mendapat skor rendah karena kedua paslon ini semuanya merupakan orang daerah. Namun rendahnya skor dalam kaitan dengan pengalaman berkomunikasi dengan orang pusat tidak membuat elektabilitas MS-Emi 
jatuh di kalangan mahasiswa karena pasangan ini mendapat skor yang tinggi di bidang lain.

Hal terakhir berkaitan dengan alasan rasional dalam memilih adalah pencermatan mahasiswa terhadap kepemimpinan para paslon, atau lebih tepat, gaya memimpin para paslon. Gaya memimpin ini dirumuskan dalam dua pernyataan, yaitu (1) tegas dalam prinsip, tegas dalam cara (fortiter in re fortiter in modo); dan (2) tegas dalam prinsip, lunak dalam cara (fortiter in re suaviter in modo). Pencermatan mahasiswa terhadap gaya memimpin para paslon ini dapat dilihat dalam dua tabel berikut.

Tabel 11. Pandangan mahasiswa tentang gaya kepemimpinan "tegas dalam prinsip, tegas dalam cara" para paslon

\begin{tabular}{|l|l|c|c|c|}
\hline No & \multicolumn{1}{|c|}{$\begin{array}{c}\text { Paslon gubernur-wakil } \\
\text { gubernur }\end{array}$} & N & $\begin{array}{c}\text { Total } \\
\text { penilaian }\end{array}$ & $\begin{array}{c}\text { Rata-rata } \\
\text { pd skala L }\end{array}$ \\
\hline 1 & $\begin{array}{l}\text { Marianus Sae-Emi } \\
\text { Nomleni }\end{array}$ & 77 & 305 & 3,96 \\
\hline 2 & BKH-Benny Litelnoni & 44 & 144 & 3,27 \\
\hline 3 & $\begin{array}{l}\text { Victor Laiskodat-Josef } \\
\text { Nai Soi }\end{array}$ & 35 & 126 & 3,60 \\
\hline 4 & $\begin{array}{l}\text { Esthon Foenay-Christian } \\
\text { Rotok }\end{array}$ & 9 & 32 & 3,55 \\
\hline
\end{tabular}

Tabel 12. Pandangan mahasiswa tentang gaya kepemimpinan "tegas dalam prinsip, lunak dalam cara" para paslon

\begin{tabular}{|l|l|c|c|c|}
\hline No & $\begin{array}{l}\text { Paslon gubernur-wakil } \\
\text { gubernur }\end{array}$ & $\mathrm{N}$ & $\begin{array}{c}\text { Total } \\
\text { penilaian }\end{array}$ & $\begin{array}{c}\text { Rata-rata } \\
\text { pd skala L }\end{array}$ \\
\hline 1 & $\begin{array}{l}\text { Marianus Sae - Emi } \\
\text { Nomleni }\end{array}$ & 77 & 218 & 2,83 \\
\hline 2 & BKH-Benny Litelnoni & 44 & 126 & 2,86 \\
\hline 3 & $\begin{array}{l}\text { Victor Laiskodat-Josef } \\
\text { Nai Soi }\end{array}$ & 35 & 102 & 2,91 \\
\hline 4 & $\begin{array}{l}\text { Esthon Foenay-Christian } \\
\text { Rotok }\end{array}$ & 9 & 18 & 2,00 \\
\hline
\end{tabular}

Gaya kepemimpinan "tegas dalam prinsip lunak dalam cara" yang merupakan terjemahan dari adagium bahasa Latin fortiter in re suaviter in modo sesungguhnya sebuah gaya kepemimpinan yang direkomendasikan sepanjang sejarah, karena sebuah prinsip memang harus tetap dipertahankan tetapi penerapannya harus dilakukan sefleksibel mungkin agar warga masyarakat dapat menerimanya. Namun dari kedua tabel di atas, yaitu Tabel 11 dan Tabel 12 terlihat bahwa mahasiswa kurang suka dengan gaya kepemimpinan yang "lunak". Secara keseluruhan, baik pada level deskriptif maupun pada level preskriptif mahasiswa tahu dan menghendaki kepemimpinan yang keras, baik pada tataran konten sebuah prinsip maupun pada cara penerapannya. Keempat paslon di atas dilihat sebagai pemimpin di bidang eksekutif dan legislatif yang tegas dalam prinsip dan tegas dalam cara, di mana MS-Emi mendapat skor tertinggi $(3,96)$ menyusul VictorJosef $(3,60)$, Esthon-Chris $(3,55)$ dan BKH-BL $(3,27)$.

\section{Alasan Primordial-Emosional Mahasiswa Memilih Paslon}

Yang termasuk dalam alasan primordialemosional adalah sifat kemerakyatan paslon, asal partai paslon, daerah asal paslon, dan agama paslon.

Tabel 13. Pandangan mahasiswa tentang sifat kemerakyatan paslon

\begin{tabular}{|l|l|c|c|c|}
\hline No & $\begin{array}{l}\text { Paslon gubernur-wakil } \\
\text { gubernur }\end{array}$ & $\mathrm{N}$ & $\begin{array}{c}\text { Total } \\
\text { penilaian }\end{array}$ & $\begin{array}{c}\text { Rata-rata } \\
\text { pd skala L }\end{array}$ \\
\hline 1 & $\begin{array}{l}\text { Marianus Sae-Emi } \\
\text { Nomleni }\end{array}$ & 77 & 326 & 4.23 \\
\hline 2 & BKH-Benny Litelnoni & 44 & 153 & 3,47 \\
\hline 3 & $\begin{array}{l}\text { Victor Laiskodat-Josef } \\
\text { Nai Soi }\end{array}$ & 35 & 127 & 3,63 \\
\hline 4 & $\begin{array}{l}\text { Esthon Foenay-Christian } \\
\text { Rotok }\end{array}$ & 9 & 39 & 4,33 \\
\hline
\end{tabular}

Yang dimaksudkan dengan sifat merakyat, ialah kebiasaan para paslon untuk turun ke tengah masyarakat dan berkomunikasi dengan mereka, berakrab-akrab dengan warga, mengapresiasi apa yang mereka kerjakan dan mendengarkan curhat serta aspirasi yang disampaikan. Dalam penilaian mayoritas mahasiswa MS-Emi merupakan pasangan yang amat merakyat dengan skor 4,23. Pasangan Esthon-Chris sesungguhnya mendapat skor yang lebih tinggi yaitu 4,33 tetapi penilaian ini diberikan oleh jumlah yang tidak signifikan. Skor yang lebih rendah dicapai oleh pasangan Victor-Josef $(3,63)$ dan skor paling kecil diraih oleh paslon BKH-BL. Dengan pengamatan sederhana, dapat dikatakan bahwa penilaian mahasiswa ini proporsional dengan keaktifan para paslon untuk "merakyat", bukan saja dalam arti turun ke desa-desa dan menemui warga, tetapi bagaimana para paslon ini dalam bahasa tubuh yang berterima menunjukkan keakraban dengan warga, mengapresiasi apa yang 
dikerjakan warga serta berempati dengan aspirasi yang disampaikan warga. Kedekatan emosional seperti ini bisa menjadi salah satu alasan mengapa warga vis-à-vis mahasiswa menjatuhkan pilihan pada paslon yang mereka sukai.

Dalam kaitan dengan alasan emosional ini agama, daerah dan partai bisa juga menjadi alasan memilih paslon tertentu. Karena itu kepada mahasiswa ditanyakan sejauh mana agama, daerah asal dan partai berpengaruh terhadap pilihan mahasiswa.

Tabel 14. Pandangan mahasiswa tentang agama paslon sebagai alasan memilih

\begin{tabular}{|l|l|c|c|c|}
\hline No & $\begin{array}{l}\text { Paslon gubernur-wakil } \\
\text { gubernur }\end{array}$ & $\mathrm{N}$ & $\begin{array}{c}\text { Total } \\
\text { penilaian }\end{array}$ & $\begin{array}{c}\text { Rata-rata } \\
\text { pd skala L }\end{array}$ \\
\hline 1 & $\begin{array}{l}\text { Marianus Sae - Emi } \\
\text { Nomleni }\end{array}$ & 77 & 171 & 2,22 \\
\hline 2 & BKH-Benny Litelnoni & 44 & 133 & 3,02 \\
\hline 3 & $\begin{array}{l}\text { Victor Laiskodat-Josef } \\
\text { Nai Soi }\end{array}$ & 35 & 84 & 2,40 \\
\hline 4 & $\begin{array}{l}\text { Esthon Foenay- } \\
\text { Christian Rotok }\end{array}$ & 9 & 29 & 3,22 \\
\hline
\end{tabular}

Di sini disebutkan agama paslon, tetapi sesungguhnya yang dilihat adalah agama gubernurnya, yaitu agama yang dipraktikkan oleh top executive di provinsi, di mana seorang pemimpin pada posisi penting dengan seluruh ciri yang ada pada dirinya sering dilihat sebagai representasi dari suatu kelompok. Apakah ada semangat identifikasi antara agama yang dijalankan oleh seorang gubernur dan penduduk provinsi?

Dari Tabel 14 terlihat sepintas lalu bahwa agama bukanlah faktor yang penting dalam memilih seorang gubernur dan wakil gubernur. Pasangan MS-Emi dengan tingkat elektabilitas paling tinggi sebesar 44,77 persen mendapat skor paling rendah $(2,22)$ ketika agama disebut sebagai alasan memilih. Tetapi reasoning terhadap rendahnya skor agama untuk pasangan MS-Emi tentulah tidak sesederhana itu. Ditahannya MS oleh KPK yang menutup peluangnya untuk maju sebagai gubernur membuat mahasiswa yang mayoritas Katolik kehilangan kesempatan untuk memilih seorang gubernur Katolik. Karena itu pilihan jatuh kepada BKH, calon gubernur yang beragama Katolik yang mendapat skor 3.02. Lalu apakah asal daerah menimbulkan semangat etnosentrisme yang mendorong seorang mahasiswa untuk menjatuhkan pilihan pada calon gubernur yang seasal dengan dirinya? Jawaban atas pertanyaan ini dapat dilihat dalam tabel berikut.

Tabel 15. Pandangan mahasiswa tentang daerah asal paslon sebagai alasan memilih

\begin{tabular}{|c|l|c|c|c|}
\hline No & $\begin{array}{l}\text { Paslon gubernur-wakil } \\
\text { gubernur }\end{array}$ & $\mathrm{N}$ & $\begin{array}{c}\text { Total } \\
\text { penilaian }\end{array}$ & $\begin{array}{c}\text { Rata-rata } \\
\text { pd skala L }\end{array}$ \\
\hline 1 & $\begin{array}{l}\text { Marianus Sae - Emi } \\
\text { Nomleni }\end{array}$ & 77 & 121 & 1,57 \\
\hline 2 & BKH-Benny Litelnoni & 44 & 98 & 2,23 \\
\hline 3 & $\begin{array}{l}\text { Victor Laiskodat-Josef } \\
\text { Nai Soi }\end{array}$ & 35 & 52 & 1,48 \\
\hline 4 & $\begin{array}{l}\text { Esthon Foenay-Christian } \\
\text { Rotok }\end{array}$ & 9 & 24 & 2,67 \\
\hline
\end{tabular}

Secara keseluruhan daerah asal mempunyai skor di bawah agama dan dari semua faktor yang mempengaruhi seorang mahasiswa untuk menjatuhkan pilihannya pada paslon gubernur dan wakil gubernur, daerah asal merupakan faktor dengan skor paling rendah kedua dari bawah setelah partai politik. Tidak berpengaruhnya faktor daerah asal merupakan sesuatu yang khas mahasiswa sebagai kelompok yang berpikir rasional. Dibandingkan dengan pemilihan yang sebenarnya pada tanggal 27 Juni 2018, daerah asal jelas sekali memperlihatkan pengaruhnya. MS-Emi mempunyai elektabilitas sangat tinggi di Ngada dan Nagekeo, BKH mempunyai tingkat elektabilitas relatif tinggi di Manggarai. Sementara praktis seluruh Timor memberikan suaranya kepada Viktor-Josef.

Pertanyaan terakhir dalam kaitan dengan alasan emosional-primordial adalah, apakah mahasiswa memilih paslon tertentu karena afiliasi partai? Mahasiswa umumnya belum berpolitik praktis dan tidak aktif sebagai anggota salah satu partai, tetapi bisa saja secara emosional dia mengidentik-kan dirinya dengan partai tertentu, dan identifikasi ini membuat dirinya menjatuhkan pilihan kepada paslon tertentu berdasarkan asosiasi dirinya dengan partai tertentu. 
Tabel 16. Pandangan mahasiswa tentang partai politik asal paslon sebagai alasan memilih

\begin{tabular}{|l|l|c|c|c|}
\hline No & $\begin{array}{l}\text { Paslon gubernur-wakil } \\
\text { gubernur }\end{array}$ & $\mathrm{N}$ & $\begin{array}{c}\text { Total } \\
\text { penilaian }\end{array}$ & $\begin{array}{c}\text { Rata-rata } \\
\text { pd skala L }\end{array}$ \\
\hline 1 & $\begin{array}{l}\text { Marianus Sae-Emi } \\
\text { Nomleni }\end{array}$ & 77 & 135 & 1,75 \\
\hline 2 & BKH-Benny Litelnoni & 44 & 57 & 1,29 \\
\hline 3 & $\begin{array}{l}\text { Victor Laiskodat-Josef } \\
\text { Nai Soi }\end{array}$ & 35 & 24 & 0,68 \\
\hline 4 & $\begin{array}{l}\text { Esthon Foenay- } \\
\text { Christian Rotok }\end{array}$ & 9 & 13 & 1,44 \\
\hline
\end{tabular}

Dari Tabel 16 di atas terlihat bahwa partai politik tidak berpengaruh atau kecil sekali pengaruhnya terhadap seorang mahasiswa untuk menjatuhkan pilihannya pada paslon tertentu.

Dari ketiga alasan emosional-primordial, yaitu agama, daerah asal dan partai, tidak ada faktor yang secara signifikan mempengaruhi seorang mahasiswa untuk menjatuhkan pilihannya pada paslon tertentu. Dengan demikian dapat disimpulkan bahwa mahasiswa menjatuhkan pilihan mayoritas pada pasangan MS-Emi karena alasan rasional dan bukan alasan emosional-primordial.

\section{Mengapa mahasiswa tidak memilih}

Dari 250 kuesioner yang disebar, terdapat 78 responden $(31,20 \%)$ yang tidak mengembalikan kuesioner. Dari jumlah ini sudah terlihat bahwa sekitar 30 persen mahasiswa tidak terlalu peduli dengan pemilihan gubernur dan wakil gubernur (memang bisa juga diinterpretasi sebagai keengganan menyisihkan waktu untuk mengisi kuesioner). Dan dari sekitar 70 persen yang mengembalian kuesioner, terdapat 7 responden $(4,07 \%)$ yang menyatakan bahwa dia tidak akan memilih gubernur. Alasan klasik yang dikemukakan adalah, dia tidak memiliki KTP, tidak tertarik dengan pemilihan gubernur, tidak percaya bahwa gubernur terpilih bisa meningkatkan kesejahteran rakyat ("ada gubernur atau tidak ada gubernur keadaan saya begini-begini saja”), ada keraguan bahwa janji-janji kampanye bisa direalisasikan dalam praktik. Skeptisisme seperti ini adalah skeptisisme khas kaum muda intelektual yang belum mengetahui dan mengalami secara kritis-partisipatoris kehidupan bernegara dan manajemen pemerintahan. Sesungguhnya jika dicermati, kondisi makro ekonomi dan perdagangan, infrastruktur, pendidikan, kesehatan tidak bisa ada dan terpelihara tanpa pemerintah. Rupanya semua kondisi ini di-taken for granted begitu saja oleh para mahasiswa.

Secara statistik alasan mahasiswa tidak memilih dapat dilihat dalam beberapa pie-chart berikut ini.

\section{Tidak ada pasangan yang mempunyai visi ekonomi yg jelas} 43 responses

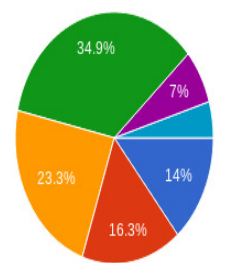

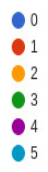

Warna pada pie-chart di atas menunjukkan intensitas sesuai dengan nomor di sampingnya. Dari pie-chart di atas ada 14 persen jawaban yang menyatakan visi misi paslon sangat tidak jelas, 7 persen mengatakan visi misi paslon tidak jelas, 34,9 persen yang berwarna hijau dan 23,3 persen yang berwarna orange berada pada posisi medioker bahwa visi dan misi paslon tidak begitu jelas untuk mereka sehingga mereka cenderung memutuskan untuk tidak memilih.

Alasan kedua mahasiswa tidak ikut mencoblos dalam pemilukada gubernur adalah pandangan mahasiswa bahwa tidak ada pasangan yang bebas dari korupsi dan nepotisme

19. Tidak ada pasangan yang bebas dari korupsi dan nepotisme

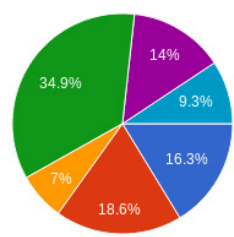

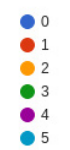

Dari pie-chart di atas terlihat bahwa ada 16,3 persen yang kurang lebih mempercayai bahwa empat paslon gubernur-wakil gubernur terbebas dari korupsi dan nepotisme, tetapi 83,70 persen dalam intensitas berbeda meyakini bahwa paslon ini tidak bebas dari korupsi dan nepotisme, baik dalam arti prosedural maupun dalam arti substantif atau kedua-duanya.

Alasan ketiga mahasiwa tidak mau ambil bagian dalam pemilukada gubernur adalah 
pandangan mahasiswa bahwa tingkat kemerakyatan para paslon ini sangat rendah.

20. Tidak ada pasangan yang merakyat 41 responses
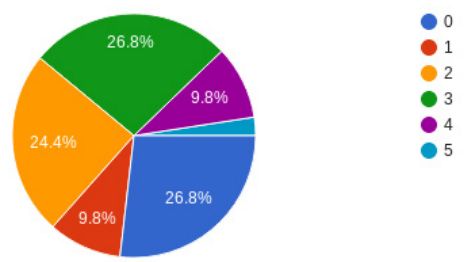

Dari chart di atas terlihat bahwa 70,80 persen responden menilai keempat paslon gubernurwakil gubernur kurang merakyat. Ada sekitar 2,4 persen yang menilai keempat paslon gubenur-wakil gubernur ini sangat tidak merakyat. Jadi ada 73,20 persen yang tidak memilih karena para paslon ini tidak merakyat. Tetapi ada 26,80 persen yang menilai paslon-paslon ini tidak merakyat tetapi tidak menjadi alasan bagi mereka untuk tidak memilih. Artinya mereka tidak memilih karena alasan lain.

Alasan keempat mahasiswa tidak terlibat dalam pemilukada gubernur karena para paslon ini, dalam pandangan mahasiswa, terlalu mengumbar janji yang berlebihan alias janji yang sulit direalisasikan dalam praktik pemerintahan nanti. Dengan singkat, paslon ini terlalu bombastis.

21. Keempat pasangan ini terlalu bombastis 41 responses

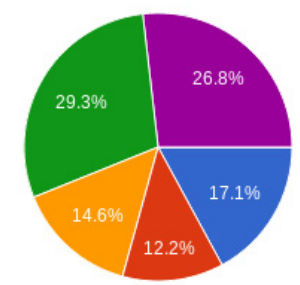

Dari chart di atas terlihat bahwa kurang lebih 17 persen responden mengakui pasangan calon gubernur-wakil gubernur menunjukkan gaya bombastis dalam kampanye atau sosialisasi diri. Selanjutnya 83 persen mahasiswa merasa para paslon terlalu bombastis dan karena itu mereka tidak berminat memberikan suaranya dalam pemilukada gubernur-wakil gubernur.

Alasan kelima mahasiswa tidak memberikan suaranya dalam pemilukada adalah ketidakyakinan mahasiswa bahwa para paslon ini bisa meningkatkan kesejahteraan rakyar NTT. Keraguan ini dapat dilihat dalam pie-chart di bawah ini.
22. Saya tidak yakin pasangan 2 ini bisa meningkatkan kesejahteraan warga NTT

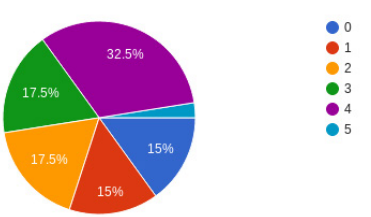

Dari chart di atas terlihat bahwa ada 15 persen mahasiswa yang meragukan kemampuan sekaligus komitmen para paslon untuk meningkatkan kesejahteraan warga NTT biarpun ini tidak menjadi alasan bagi mereka untuk tidak memilih. Ketidakterlibatan mereka dalam memberikan suara dalam pemilukada gubernur disebabkan oleh alasan lain. Ada kurang lebih 2,5 persen yang berada pada posisisi ekstrim, yaitu sama sekali tidak percaya akan kemampuan para paslon untuk meningkatkan kesejahteraan rakyat NTT. Kurang lebih 50 persen berada pada posisi moderat, dalam arti mereka tidak yakin para paslon ini mempunyai komitmen total untuk memperhatikan dan meningkatkan kesejahteraan rakyat NTT, meskipun mereka tahu keberadaan mereka sebagai gubernur dalam kadar tertentu berpengaruh terhadap peningkatan kesejahteraan rakyat NTT.

Alasan keenam mahasiswa tidak memberikan suaranya dalam pemilukada gubernur adalah kecemasan bahwa para paslon ini akan mencari dana untuk menutup belanja kampanye yang sangat besar. Kecemasan ini dapat dilihat dalam pie chart di bawah ini.

23. Saya pikir, pasangan2 ini akan mencari danauntuk menutup biaya kampanye yang sangat besar

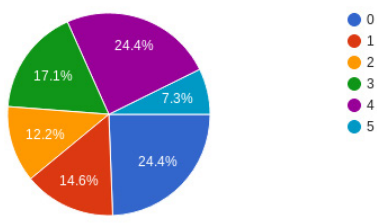

Dari pie-chart di atas terlihat bahwa kurang lebih 75 persen mahasiswa tidak memilih karena kecemasan (dengan intensitas berbeda, dari kecemasan yang biasa-biasa hingga kecemasan yang sangat intens) bahwa pasangan ini akan mencari dana untuk menutupi dana kampanye yang sangat besar $^{1}$, sementara hampir 25 persen punya

\footnotetext{
Data tidak resmi menyebutkan, pasangan Victor-Josef menggelontorkan dana mendekati satu trilyun rupiah sementara
} 
kecemasan yang sama tetapi ini tidak menjadi alasan bagi mereka untuk tidak memilih. Mereka tidak memilih karena alasan lain.

Alasan ketujuh mahasiswa tidak memilih adalah sikap indiferen, yaitu bahwa bagi mereka ada gubernur atau tidak ada gubernur sama saja. Tentu saja sikap ini lahir dari wawasan yang masih sempit dan ketidaksadaran bahwa seluruh kondisi makro ekonomi, pendidikan, kesehatan dan perdagangan hanya bisa terselenggara secara baik karena adanya pemerintah. Sikap indiferen mahasiswa dapat dilihat dalam pie chart di bawah ini.

24. Bagi saya, ada gubernur atau tidak, tidak penting 41 responses

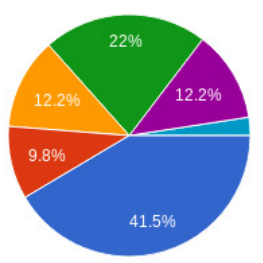

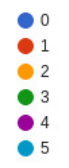

Dan alasan kedelapan mahasiswa tidak memilih adalah bahwa para paslon tidak menjawabi aspirasi mahasiswa. Yang menjadi aspirasi mahasiswa sesungguhnya dapat dilihat pada bagian berikut. Ada banyak harapan yang diletakkan para mahasiswa di pundak para paslon, tetapi yang menjadi perhatian utama adalah peningkatan kesejahteraan rakyat, peningkatan mutu layanan kesehatan, perhatian pada pendidikan tinggi dan kerukunan antarumat beragama.

25. Tidak ada pasangan yang menjawabi aspirasi saya 40 responses
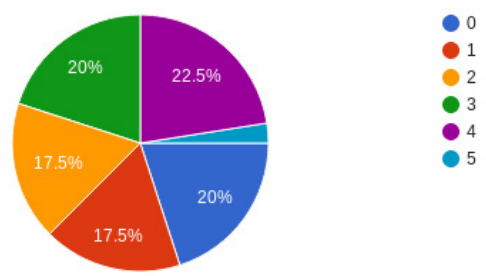

Dari chart di atas terlihat bahwa 80 persen dari mahasiswa non-voters tidak memberikan suaranya karena merasa bahwa aspirasinya tidak akan terpenuhi, sementara 20 persen juga perpendirian bahwa para paslon ini tidak akan memenuhi aspirasi mereka tetapi ini bukanlah alasan bagi mereka untuk tidak memilih.

pasangan BKH-BL menghabiskan dana sekitar 200 milyar rupiah

\section{Harapan Mahasiswa}

Harapan mahasiswa dengan intensitasnya dapat dilihat dalam tabel berikut.

Tabel 26. Harapan Mahasiswa tentang Apa yang Bisa Dikerjakan Gubernur Terpilih

\begin{tabular}{|c|c|c|c|c|c|c|}
\hline \multirow{2}{*}{ No } & \multirow{2}{*}{$\begin{array}{c}\text { Harapan Mahasiswa } \\
\text { terhadap Gubernur } \\
\text { Terpilih }\end{array}$} & \multicolumn{4}{|c|}{ persentase } & \multirow{2}{*}{ Rerata } \\
\hline & & MS & $\mathrm{BKH}$ & VIC & EST & \\
\hline 1 & $\begin{array}{l}\text { Meningkatkan } \\
\text { kesejahteraan rakyat } \\
\text { NTT }\end{array}$ & 89,09 & 85 & 85,14 & 93,33 & 88.14 \\
\hline 2 & $\begin{array}{l}\text { Memperbaiki sistem } \\
\text { pendidikan dasar dan } \\
\text { menengah di NTT }\end{array}$ & 83,64 & 80 & 77,71 & 73,33 & 78.67 \\
\hline 3 & $\begin{array}{l}\text { Meningkatkan mutu } \\
\text { kesehatan masyarakat } \\
\text { NTT }\end{array}$ & 85,19 & 85 & 70,86 & 93,33 & 83.59 \\
\hline 4 & $\begin{array}{l}\text { Memberantas korupsi } \\
\text { dan nepotisme dari } \\
\text { bumi NTT }\end{array}$ & 83,38 & 80,45 & 81,14 & 62,22 & 76.80 \\
\hline 5 & $\begin{array}{l}\text { M e m p e r b a i k i } \\
\text { infrastruktur NTT }\end{array}$ & 82,34 & 83,64 & 74,85 & 66,67 & 76.87 \\
\hline 6 & $\begin{array}{lr}\text { Menciptakan } & \text { iklim } \\
\text { yg kondusif } & \text { bagi } \\
\text { perbaikan } & \text { pasar } \\
\text { komoditi } & \\
\end{array}$ & 70,65 & 69,54 & 61,14 & 64,44 & 66.44 \\
\hline 7 & $\begin{array}{l}\text { M e n c i p t a k a n } \\
\text { lapangan kerja bagi } \\
\text { pengangguran }\end{array}$ & 77,66 & 75,45 & 72 & 71,11 & 74.05 \\
\hline 8 & $\begin{array}{l}\text { Membuka lembaga } \\
\text { pelatihan ketrampilan } \\
\text { bagi pengangguran }\end{array}$ & 77,40 & 75,45 & 71,43 & 60 & 71.07 \\
\hline 9 & $\begin{array}{l}\text { Mencegah buman } \\
\text { trafficking di NTT }\end{array}$ & 83,64 & 72,73 & 68 & 60 & 71.09 \\
\hline 10 & $\begin{array}{l}\text { Me m p e rju a ngkan } \\
\text { penegakan hukum } \\
\text { bagi yang tertindas }\end{array}$ & 81,04 & 76,36 & 65,71 & 60 & 70.78 \\
\hline 11 & $\begin{array}{l}\text { M e m p e r h a tik a } \mathrm{n} \\
\text { pendidikan tinggi di } \\
\text { NTT }\end{array}$ & 82,86 & 76,82 & 66,86 & 71,11 & 74.41 \\
\hline 12 & $\begin{array}{l}\text { M e m e } 1 \text { i h a r a } \\
\text { kerukunan antarumat } \\
\text { beragama di NTT }\end{array}$ & 85,97 & 81,82 & 73,14 & 71,11 & 78.01 \\
\hline & Rerata & 81,90 & 78,52 & & 70,55 & \\
\hline
\end{tabular}

Yang dimaksudkan dengan persentase dalam Tabel 26 di atas adalah intensitas harapan mahasiswa dalam skala Likert yang telah dikonversikan ke dalam rentang angka 0-100. Jadi misalnya angka sempurna untuk harapan mahasiswa kepada MSEmi dalam meningkatkan kesejahteraan rakyat NTT adalah 385 sementara total skor untuk harapan kepada MS-Emi dalam meningkatkan 
kesejahteraan rakyat NTT adalah 343 atau 89,09 persen. Bila direratakan, harapan terbesar mahasiswa diletakkan di atas pundak MS-Emi $(81,90)$, berikut BKH-BL $(78,52)$, Victor-Josef $(72,33)$ dan EsthonChris (70,55). Mahasiswa mengharapkan keempat paslon untuk dapat melaksanakan berbagai bentuk pelayanan publik tetapi ada empat hal yang menjadi perhatian pokok, yaitu peningkatan kesejahteraan rakyat $(88,14 \%)$, peningkatan mutu kesehatan rakyat NTT (83,59\%), perbaikan sistem pendidikan dasar dan menengah $(78,67 \%)$ dan terpeliharanya kerukunan antarumat beragama $(78,0 \%)$. Harapan cukup besar juga ditujukan kepada terlaksananya pemberantasan korupsi dan nepotisme (76,80 $\%)$, perbaikan infrastruktur $(76,87 \%)$, perhatian kepada pendidikan tinggi di NTT $(74,41 \%)$ dan penciptaan lapangan kerja bagi pengangguran $(74,05$ $\%)$. Menarik untuk disimak bahwa skor terendah diberikan kepada terciptanya iklim yang kondusif bagi perbaikan pemasaran komoditi, padahal NTT dengan mayoritas penduduk bermata-pencaharian petani dan pengusaha tanaman perdagangan sangat mengandalkan perdagangan komoditi untuk peningkatan kesejahteraan. Apresiasi yang tidak begitu tinggi juga diberikan kepada dibukanya balai latihan kerja bagi para pengangguran, padahal penciptaan lapangan kerja yang juga menjadi salah satu harapan mahasiswa bergantung, antara lain, kepada tingkat ketrampilan yang diperoleh dari pelatihan di balai latihan kerja.

Di sini terlihat kekurangmatangan penilaian mahasiswa dalam membangun aspirasi terhadap para pasangan calon gubernur-wakil gubernur. Aspirasi seperti ini dapat dimengerti mengingat wawasan mahasiswa yang masih sempit dan pengalaman hidup yang masih minim. Dengan kata lain, mahasiswa mengaspirasikan peningkatan kesejahteraan rakyat, tetapi tidak cukup cerdas dan cermat untuk melihat hal apa saja yang patut dilakukan untuk meningkatkan kesejahteraan rakyat. Penilaian dan sikap seperti ini kurang lebih konsisten dengan sikap yang mengatakan bahwa "ada gubernur atau tidak ada gubernur, nasib saya begini-begini juga” - mahasiswa tidak sadar bahwa tanpa gubernur, infrastruktur tidak dibuat dan dikelola, sistem perdagangan tidak terkontrol, fasilitas publik untuk kesehatan, pendidikan dan transportasi tidak tersedia.

\section{Kesimpulan}

Setelah melakukan analisis terhadap preferensi dan voting behavior di kalangan mahasiswa Unwira, penulis sampai pada beberapa kesimpulan sebagai berikut:

1. Dalam kaitan dengan preferensi, mahasiswa cenderung memilih pasangan calon gubernurwakil gubernur berdasarkan rekam jejaknya, dan bukan berdasarkan apa yang disampaikannya dalam kampanye. Rekam jejak yang dimaksud adalah tindakan konkret yang sudah dilakukan untuk meningkatkan kesejahteraan rakyat. Mahasiswa juga suka dengan paslon yang merakyat, tidak hanya dalam arti secara fisik turun ke desa, tetapi bagaimana paslon mendengarkan secara simpatik dan empatik aspirasi yang disampaikan warga. Selanjutnya alasan-alasan primordial-emosional seperti kesamaan daerah, kesamaan agama, kesamaan partai tidak berpengaruh signifikan terhadap keputusan mahasiswa untuk memberikan suara dalam pemilukada.

2. Sebagai kelompok intelektual, mahasiswa cukup kritis terhadap berbagai program yang ditawarkan para pasangan calon gubernurwakil gubernur, tetapi karena wawasan yang belum luas dan usia yang masih muda dengan pengalaman yang minim, mahasiswa cenderung skeptis dan indiferen terhadap berbagai program yang ditawarkan sampai ke tingkat non-partisipatif dalam pemilukada gubernurwakil gubernur seraya men-take for granted semua fasilitas publik yang dinikmati. Nonvoting behavior diperlihatkan oleh kurang lebih 30 persen mahasiswa, sementara voting behavior diperlihatkan oleh kurang lebih 70 persen mahasiswa.

3. Yang diaspirasikan mahasiswa adalah bahwa calon gubernur-wakil gubernur bila terpilih dapat melakukan berbagai program pembangunan dengan tekanan utama pada peningkatan kesejahteraan rakyat, perbaikan kesehatan, perbaikan sistem pendidikan dasar dan menengah, dan pemeliharaan kerukunan 
antarumat beragama. Padalevel kedua mahasiswa mengharapkan agar gubernur terpilih dapat memperbaiki infrastruktur, mencegah korupsi dan nepotisme dan menciptakan lapangan kerja bagi pengangguran.

4. Walaupun mahasiswa mengaspirasikan peningkatan kesejahteraan rakyat dalam semua aspek, mahasiswa tidak cukup cerdas melihat sektor-sektor yang turut menciptakan iklim yang kondusif bagi peningkatan kesejahteraan seperti perbaikan makro tata niaga komoditi dan pelatihan tenaga kerja.

\section{Saran}

1. Mahasiswa perlu diberi pencerahan bahwa kehadiran pemerintah, casu quo gubenur-wakil gubernur, merupakan suatu conditio sine qua non bagi upaya peningkatan kesejahteraan rakyat. Dengan demikian mahasiswa tidak bisa bersikap indiferen dan mengambil posisi non-voting dalam ajang seperti dan sepenting pemilihan gubernur dan wakil gubernur.

2. Sebagai kelompok muda terdidik, mahasiswa bisa dicerahkan dan dimotivasi untuk berkontribusi positif bagi pemerintah, baik melalui pemikiran kritis maupun melalui karyakarya inovatif bagi peningkatan kesejahteraan rakyat dan kemajuan bangsa umumnya.

\section{Bibliografi}

Arianto, Bismas. 2011. "Analisis Penyebab Masyarakat Tidak Memilih dalam Pemilu", Jurnal Ilmu Politik dan Ilmu Pemerintahan, Vol. 1, No. 1.

BPS. 2016. NTT Dalam Angka.
Bryman, Alan. 2004. Social Research Methods. New York: Oxford University Press.

Budiarjo \& Setyawan, Ign. Agng. 2015. "Perilaku Memilih di Kalangan Mahasiswa Malaysia di Indonesia dalam Pilihan Raya Umum Malaysia ke 13”. Spirit Publik Volume 10, Nomor 1 April.

Esita, Zulaeni. 2014. "Pengaruh Kelompok

Rujukan dan Kepribadian Otoritarian terhadap Perilaku Memilih pada Pemilih Pemulaz”. JIE Volume III No. 1 April.

Lipset, Seymour Martin. 1981. Political Man, the Social Bases of Politics. Baltimore, Maryland: The John Hopkins University Press.

Muslim, Agus. 2013. Faktor-faktor Partisipasi Politik Pemilih Pemula di Kecamatan Andir pada Pemilihan Gubernur dan Wakil Guberur (Pilgub) Jabar 2013. Skripsi, FISIP, Universitas Komputer Indonesia.

Newman, W. Lawrence. 2003. Social Research Methods. Qualitative and Quantitative Approaches. Boston: Pearson Education Inc. Pradhanawati, Ari. 2010. "Perilaku dan Sikap Sosial Politik Mahasiwa dalam Pilpres 2009". Jurnal Masyarakat Kebudayaan dan Politik, Vol 23, No 3.

Suryanef. 2011. "Persepsi Politik Mahasiswa FIS Universitas Negeri Padang”, DEMOKRASI Vol. X No. 2.

\section{Internet:}

PosKupang.com 9 Feb.2017

sergapntt.com 24/4/2012

nomor1.com 